\title{
National Mechanisms for Ensuring Social Rights
}

\author{
Shahriyar Aliyev \\ Baku State University, Azerbaijan
}

\section{Introduction}

The epoch of globalization, as well as a social and legal relations in all spheres of life is characterized by a number of theproblems and the dynamics of the development of the society in compliance calls into question a reliable guarantee of these rights. In spite of the fact that the social rights acted as a guarantee of worthy human life and the protection of these rights in a holistic approach to national legislation and good governance is still not in sufficient level. The problem of demography, the backwardness of socio-economic and cultural development, the degradation of education, health and ecosystems, the food problem, poverty, dissatisfaction with the health system, drug addiction and other factors do not guarantee the reliable protection of social rights. Besides here it is possible to add indifference in observance with rules of international law, continuations of intensive military threats, the struggle for power of leading states, etc. of the political factors and it first of all influences the social life of people. In addition, between recognition of the social rights and their real realization, between the high level of social relevance of the constitutional definition with an unjustified low level of theoretical understanding of the content of these rights, formation of separate social rights institutes accompanying serious non-compliance in systems of public administration demands a new approach to the solution of the social problems. It is incontestable that, in spite of the fact that theoretical questions have been solved, but the rights of socially vulnerable groups of the population still proves important questions (access to justice, indifference and unethical behavior of administrative bodies and, etc.). Although the positive manifestation of the activities of the Azerbaijan Republic in the implementation of social rights, but still some of the most important problems for consideration in this regard should be considered appropriate.

\section{Issues of social rights protection in the constitutional control system}

Constitutional control, as one of the dimensions of state political regime, has the nature of provision of human rights and fundamental freedoms, and prevention of the "power of tyranny and anarchy" (13, p. 32). This institution eliminates the 
collision in the legislative system; provides harmonious and logical development in law-enforcement practice; prevents conflicts in the socio-political subject; and monitors the behavior of main subjects of political system.

Constitutional control institution leading the way directly to authorities of the Constitutional control of the people and citizens, occupies an important place in the system of constitutional justice. It first protects a person from the executive power with overly growing bureaucratic bodies, the threat coming from the judiciary, able to settle the case according to the rule of the law. Its importance is that, in legal system argumentation of the regulation act or judicial experience not corresponding to Constitution and leading to the violation of rights and freedoms in Constitutional control, ensures flexibility for the Constitutional process (11, p. 148).

Although the implementation of the constitution control in separate countries differs irrespective of legislation characteristics, the forms of control execution are systematized differently for distinct (similar) symptoms and specific basis in different sources. So, F. Abdullayev divides constitutional control forms into: initial and subsequent; concrete and abstract; reasonable and optional; formal and material; solvent (decision-making) and advisory; full and partial; internal and external (2, p. 20). Nevertheless E.Lukasheva mentions three basic forms of such control: abstract, concrete and individual control (8, p. 422).

Priority principle of human and civil rights and freedoms ratified in Constitution of Azerbaijan Republic (AR) coordinates all aspects of state power with these laws and commits them to duty. In this sense, Articles 12, 26, 71, 149 are particularly significant. The preamble of the Constitution of AR creates the opportunities to provide decent standard of living for all people; Azerbaijan people's devotion to human rights and freedoms; intention to develop culture, economy, and political and legal institutions to ensure a decent level of life; verification of the extensive list of social rights on constitutional level along with showing importance of these rights; its protecton via constitutional justice in accordance with fair economic and social orders. The Constitutional Court (CC) important function of which is to protect human and civil rights and freedoms, acts as the competent authority for style, method, volume and position of its activity in constitutional control sphere. In this sense, the issues over social rights protection in the rule of constitutional control, concerning most urgent and important problems of human rights and freedoms, remain less-developed issues in terms of constitutional theory and practice.

However, the state's social policy is finding expression in the Constitution and other social legislation is not guarantee of their realization in real life. In other 
words, to write and adopt a proper constitution and laws is still not enough for the country's democratic development and the just rule of law. Therefore, states create these legal institutional and legal procedures system with the purpose of protection of social rights and its executives bodies' remaning within Constitution norms and in this direction Constitution control which acts towards providing the predominant legal power of Constitution norms, plays active role.

Therefore, $\mathrm{CC}$ providing protection from unconstitutional laws in the sphere of social rights, refers to other constitutional norms and principles, not provisions detected basic social rights of AR Constitution in making decisions and Articles 7, $12,16,25,26,60,71,148$ and 151 of the Constitution are important in this respect. Also, CC applied to international law norms in its almost all decisions over this category and referred fundamentally to provisions of UDHR; the International Covenant on Economic; Social and Cultural Rights; as well as the International Labour Organization Conventions ratified by the Republic of Azerbaijan.

At present, the experience of the Constitutional Court of the Republic of Azerbaijan in the field of protection of rights and freedoms in the social sphere is wide enough. The Court, in particular, has considered a number of issues on protection from discrimination for age in labor relations; provision of access to justice in the resolution of labor relations; groundless banning of strikes for certain categories of workers upon collective labor conflicts; the restriction of the right to social security during unemployment and in case of illness; pensions of those imprisoned by the court's verdict and also who went abroad for permanent residence from AR.

Analysis of the decisions made, allows generalization of the position of the Court on the content of social rights specified in the Constitution; the degree of freedom of the legislator in the regulation of these rights; possibilities and the limits of protection of individual rights and freedoms via constitutional justice in labor and social security, as well as the impact of Court decisions on the development of legislation in this area.

AR CC is taking into account legal character and essence of labour pensions due to international practice and considering the urgent validity of social provision right of condemned retired people, considered Article.109 of AR Law on "Citizens' pension provision" void being incompliant to AR Constitution with decision dated 29 December 1999.

Furthermore, Constitutional Court considered null Part II of Article. 132 of AR Labour Code on non-inclusion of penalty term of people sentenced to correctional labor without confinement in length of service on the basis of the request of the 
Supreme Court of Azerbaijan Republic since restricting the right for rest, as enshrined in Article. 37 of Constitution.

Providing the samples from CC's practice would be to continued, but we hope that, facts shown above give the general idea of the constitutional basis of protection of social rights, the possibility of the defense, via $\mathrm{CC}$. Review of the cases proves that $\mathrm{CC}$ can influence the formation and implementation of the state's social policy wthin the framework of abstract legal norms to a certain extent. This effect is not always manifested as social rights protection. However, the Constitutional Court has contributed to the improvement of the country's legal system, legal regulation integrity and consistency.

It must be considered in relation to the legal nature of social rights that, though ensure of defense and protection of other rights enshrined in the Constitution (personal, economic, political and cultural) equally with social rights, there are a number of specific features in provision and implementation of these rights. Thus, as opposed to personal, economic, political and cultural rights to a certain extent, the effective implementation of social rights is associated with state's financial opportunities for their provision. The mentioned above is also reflected in international acts (2, p. 120).

$\mathrm{CC}$ resolving disputes on the interpretation of Constitution provides the development of constitutional content without changing the text of the relevant Constitution articles on social protection. Some decisions of CC on the issues over controversy review and commentary create the rules, and justify and legitimate legality of other social process as a legal fact. CC solves issues of what extent constitutional norms observed in social organizations' activities (7, p. 442-443).

Thus, the decisions of $\mathrm{CC}$ of the Republic of Azerbaijan in the field of social rights protection can have a positive impact on law-making and law-applicative practice of citizens' social defense. Tirst of all the active role of the Constitutional Court, is reflected, in revealing constitutional nature of social rights of citizens, giving them the absolute and integral rights of the quality.

\section{Judicial protection of social rights}

Judicial provision of rights and freedoms are fundamental human rights stipulated by international law norms and the Constitution of Azerbaijan Republic. The right to the protection by court provides not only the possibility of starting proceedings in civil cases, but also the proper organization and composition of the court, as well as state ensure of the course. 
The right to appeal to the court is a reliable guarantee for the protection of civil, family, labor rights and the rights of other citizens (12, p. 135). The right can be used by the citizen of the relevant state, also foreigners and persons without citizenship. One of the guarantees of implementation of judicial protection right at full extent is right of judicial review of one's case enshrined in Article. 62 of the Constitution as prescribed by law and one's case may not be heard in another court without consent. A similar provision is provided in Article. 4 of the Code of Criminal Procedure (CCP).

The right to judicial protection is realized by general (regional or municipal) and specialized (administrative and economic) courts. Civil and economic disputes are resolved by being considered in a civil legal proceeding, while, economic disputes investigated in the administrative legal proceeding. Court is obliged to investigate all important facts for the resolution of merits, since burden of proof lies with the parties due to the nature of the cases in civil proceedings, in the administrative proceedings, not satisyfied with the evidence provided by the process parties and other materials. This kind of legal defense can be used on the basis of dispositiveness principle.

The right to the protection of the legal proceeding obtains specific qualities depending on the features of proceedings, akind of government activity. As opposed to civil, administrative and arbitration legal proceeding dominated by the principle of dispositiveness, crime process demanded from criminal authorities to institute criminal prosecution over each case, detected any signs and to take measures as provided by law for the determination of crime and punishment of the guilty persons. In other words, regardless of a request of the victim on detaining and punishing accused and even, contrary to one's wishes (except for certain category of cases), officials must carry out follow-up investigation (ex of-ficio) according to their position.

State's task to absolutely punish any offender is one of the main purposes of criminal proceedings and this task is specified by Article 68. of the Constitution in this way: "Rights of the person suffered from crime and also from the usurpation of power are protected by law. Everyone has the right to compensation for losses by the state borne as a result of illegal actions or non-action of state bodies or their officials".

An institution on appealing to the court implements judicial supervision, completely new for the criminal procedural. This institute fulfils judicial review over the actions and decisions of officials of criminal prosecution bodies in case of the possibility of violation of the rights and freedoms. During the proceedings, the 
court carries out two tasks: provision of legality of separate actions and decisions made by officials and the bodies in charge of the criminal prosecution; and protection of rights and freedoms of instigators of criminal process (excluding groundless and illegal restriction, putting to an end violations of rights and restoration of broken rights) (1).

Objectives of criminal law are formed on the basis of socio-economic problems solved by society and the state in different stages of development (3, p. 16). Therefore, the protection of social rights of the person is carried out by means of criminal law; rights and legal interests of persons belonging to the sphere of such laws are protected, and their criminal legal actions are covered by a more humane punishment in relation to other population groups.

During the crime judgment, the issue of legal assistance to low-income individuals is of particular importance. Attorney renders free legal assistance from the state fund to suspected or accused persons in accordance with the legislation of thweAzerbaijan Republic over administrative criminal cases and for low-income persons in need of legal aid in court without any restrictions. Constitution of the Republic of Azerbaijan identifies specialized legal assistance right for free of charge (14), taking into account the financial resources of the state, especially, with regard to in socially underprivileged layer of the population and the importance of these criteria is not doubtfultherein (5, p. 344).

Also, certain provisions are stipulated due to criminal law for separate population groups belonging to the sphere of social rights of human and who need more legal protection. Thus, the CM intends tougher penalties for crimes against juveniles, including children who are slightly younger and below fourteen years of age, pregnant women and other vulnerable persons and criminal legal acts committed by them humanized rather than others.

Except for people sentenced to imprisonment for a term of over five years for committing severe or very serious crime against the person, the court may postpone the withdrawal of sentence of pregnant women or women with children under eight years of age, as well as, before child's reaching the age of eight by men who brought up him alone. When children reached eight years of age, court releases convicted person from the remained part of the sentence, or replaces it by a lighter sentence, or sends convicted person to appropriate establishment for the rest of the sentence.

Issues of criminal liability of juveniles (children) are covered in a separate section of Criminal Code (V section). The affairs such as the concept of persons, the possibility of imposing punishment and alternative form of punishment, types of 
the punishment to be imposed, conditions are considered when determining the penalty, release from it and conditionally, early release from the sentence. Article. 20.2 of Criminal Code of Azerbaijan Republic determines the legal age of criminal liability for person who has reached the age of 14 .

Along with the afore-mentioned, upon being exempted from criminal liability or punishment for juveniles, terms on release from criminal liability in connection with expiry and judgment execution is partially decreased and terms of sentence reduced.

Severe punishment is imposed for the following cases: acts of rape and sexual violence committed against a person under the age of fourteen, and juveniles; crimes of trafficking against them; involving them in the armed forces; punishment; trafficking and illegal actions over documents; forced labor restricting a person's freedom, urging to do certain work (service); unlawful imprisonment not connected with kidnapping; taking hostages; homicide against women; torture; artificial insemination or embryo implantation of woman, without her consent or juveniles; kidnapping and illegal actions with documents for this purpose; forced labor; unlawful imprisonment; taking of hostages.

In the social sphere within the framework of the right to health, in accordance with the law, or special rules, medical officer's unableness to render medical aid to the patient without sufficient excuse who is obliged to provide medical assistance bears criminal responsibility as a result of one's bodily damage. In this sphere violation of norms of labor right (violation of labor safety rules (14); labor contract- involvement of a large number of workers in the execution of any works (services) before contract's entry into force (14)) led to criminal responsibility.

Crime liabilities considered above in respect of children do not express norms of the Criminal Code at all in criminal law defense of women and children. In addition, the chapter "Crimes Against Juveniles and Family Relations" has been included to VIII section "Crimes Against the Person" of Criminal Code, that emraces only independent crimes on the entire family and juveniles' criminal legal protection.

Crimes against juveniles and family relations can be divided into two groups: crimes related to violation of educational interests of juveniles (involving juveniles in criminal activities; implicating juveniles to engage in prostitution or immoral acts); damage to the interests of juvenile or a whole family (trafficking in child pornography; changing other person's child; trafficking of juveniles; illegal child adoption; reveal of adoption mystery; and forcing women to marry). 
Obstructing the lawful business activities occupies a special place among crimes in socio-economic activity. Obstructing the lawful business activities involves the abuse of business duty in the sphere of state regulation of this activity. The direct object of the crime is rletaed to regulation of business activity by public authorities. Free legal ownership right is an additional object. Actions aimed to prevent legitimate business activities are: illegal refusal of registration of business activity; evade of registration of business activity; illegal refusal of special permit (license) to carry out the business activity; evade of issuing special permit (license) to carry out the business activity; restriction of the rights and legitimate interests of persons engaged in business activities; illegal interfere with business activities in different kind of ways.

Important elements of the right to live in a healthy environment are protected by the criminal law. Thus, chapters 26-28 of Criminal Code covers the norms encroaching public health, public morality and the environment; socially dangerous actions causing damage or harm, or capable of damaging the facilities of criminal law protection. Crimes against living in a healthy environment can be divided into three groups depending on the direct object: crimes related to illicit trafficking in narcotic drugs and psychotropic substances; crimes encroaching on public morality; and environmental crimes.

Social objects along with being protected by "Crimes Against Property" chapter, as well as "War Crimes" comprise the criminal law object. Thus, in accordance with Article 116.0.8 of Criminal Code to attack the places which are not military target, clearly visible and distinctive religious, educational, scientific, charitable and medical facilities, and where the sick and wounded placed, without military necessity, is considered a particularly serious crime.

So, social rights being protected by criminal law and from criminal attacks, the sphere of influence and realization provisions of the rights seriously affect development dynamic of the criminal law. Also, the level of the rule of law and democracy can be higher within the framework of social rights, and protection from attack to human rights and freedom will be more confident when role of juridical or court of justice is high and how much the freedom and independence of the court higherin mutual relations with local governing bodiess or the competent authorities. In such cases, the court is a reliable guarantor of human rights and fundamental freedoms over a dispute arising in relations between the citizen and the state.

Today quite important issues stand before the judiciary. This first of all, is connected with the right of court protection. So, 1,982 appeals related only to the 
provision of this right were submitted to the Ombudsman in 2015. Sometimes, the position of charges prosecutor is taken as a basis for making a decision in criminal cases. Acquittal judgements are given in the courts of higher instance rather than courts of the first instance. The mistakes of primary investigation body are not assessed accordingly, the position of the court is still maintained in the formal images over the provision of competition principle (such asrelated to the right to defense, formal procedure on the accused person's retaining a lawyer at public expense.). For example, during the implementation of civil and administrative cases indifference of the authorities still exist in respect of juridical requests and artificial barriers upon the execution of court decisions.

In addition, the other side of the problem is that, though decisions were sent to the applicant as shown in responses to questionnaires adressed to the court timely, given the complaints on non-validness of judicial decisions and even re-sent after that request, during the investigation it is known that, it does not reflect the fact in some cases (9). It means that, courts which are considered a just settlement of disputes, continue to give false information in response to inquiries to even competent and prestigious institutions in order to cover up their mistakes. Such circumstances cause decrease of high-confidence against the court, in general, the power of the state.

\section{Administrative and legal forms of protection of social rights}

Safeguard of rights in the social sphere, is directly connected with the effectiveness of management mechanism arising from administrative function of the state. Administrative functions stipulate ensuring making political decisions (10,p. 103). In some law literature, in social and cultural spheres public administration is related to management of an organization of work in science, education, culture, social protection, health, youth policy and sports, statistics and archives (4, p. 508).

Administrative and legal forms of protection of citizens' social rights can be divided into: 1) the president control; 2) legislative control; 3) the prosecutor control; and 5) authority control.

Presidential control has an important role in the protection of social rights. According to Constitution (Article. 8), The President of the Azerbaijan Republic is the Head of the Azerbaijani state and has wide constitutional competences for fulfilling functions. First, the executive power belongs to the President of the Republic of Azerbaijan and he has competences on forming public authorities. In addition, the President of the Azerbaijan Republic is guarantor of independence and territorial integrity of the Azerbaijani state, observance of international agreements wherein the Azerbaijan Republic is one of the parties, that is important 
in implementation of the social rights guaranteed by international law. President of the Republic of Azerbaijanby implementing appropriate action, establishes important safeguards for the protection of social rights.

For the implementation of executive competences the President of Azerbaijan Republic establishes Cabinet of Ministers of Azerbaijan Republic (Article. 114). Cabinet of Ministers of Azerbaijan Republic carries out control over ministries and other central bodies of executive power annul their acts; provides implementation of state social programs. The government is implementing the constitutional rights of citizens in the field of social protection; takes measures for the realization of the citizens' labor rights, health care, the right to a favorable environment; identity's security, the rule of law, provision of human rights and freedoms, property and public order, crime prevention.

However, tasks are set to ensure the implementation of constitutional rights of citizens by executive authorities in different laws and in-force law regulations concerning social rights and main role here belongs to Code of Administrative Offenses (CAO). According to the $\mathrm{CAO}$, social rights fields can be grouped as follows within administrative offenses: the right to education; social protection; social security; children's rights; labor rights; trade unions; health care protection; living in healthy environment; the right of ownership.

Due to to Code of Administrative Offenses (CAO), reproaches against administrative violations by various groups in the sphere of influence of the social rights are humanized; hardened for offenses committed against them. Thus, hunting firearms, ammunition and other hunting guns of persons, the main source of living of whose is hunting must not be confiscated, right of hunting of such persons, not restricted. Administrative affairs and administrative detention can not be applied to 1st and 2nd group of disabled, unhealthy children, pregnant women and women with children under the age of eight, men bringing up children under the age of eight alone, those women and men who have reached the retirement age; the administrative detention of persons under eighteen years of age; administrative removal can not be applied to those who have refugee status or political asylum in the Republic, as well as victim children of human trafficking beyond AR. Juveniles (under sixteen) and pregnant women can not be applied repatriation. The commitment of administrative crime by minors, pregnant women or women who have an underage child is considered as mitigating responsibility when imposing administrative penalties and involving juveniles in the commitment of administrative violation, an administrative offense's commit against juveniles shall be deemed aggravating circumstances. 
Lawyer's participation is important in cases of arrest of juveniles, as well as dumb, deaf, blind, other people with physical or mental disabilities who can not exercise their right to defend themselves in the administrative order. The refusal of the person whom the administrative offense is instituted against, of the defense will not be accepted (14). In case lack of finance to hire a lawyer at their own expense, legal aid is made to him according to the state expense due to the administrative procedure (14). Juvenile cases on administrative violations are conducted under the supervision of the prosecutor.

A citizen may lodge a complaint to a higher body (official) on imposed administrative responsibility measures and is obliged to examine and decide on it within the period specified. Mitigating or canceling acts have a retroactive effect. The execution of the cases on administrative law violation cases is carried out on the basis of the law in force at the time of case consideration.

Administrative jurisdictional authorities are obliged to observe basic principles including legality, provision of immunity with the constitution, ensuring the protection of honor and dignity of human and citizen, and justice and the presumption of innocence (6).

\section{The role of the authorized institution in the field of protection of social rights}

The institution contributes to the elimination of deep contradictions between state and civil society institutions; legitimizes the power; informs the citizens about public servants' actions and abuses. Attorney takes effectual measures against bureaucracy as serious obstacle, as well as bureaucratic, seniors arbitrariness and indifferent attitude to the citizens' appeals and problems of human and civil rights and freedoms.

In total, 130,010, whereas during the year 2015, only 15,320 applications were addressed to an attorney, which is $16.5 \%$ more compared to 2014 in the Republic of Azerbaijan. Nearly $72.6 \%$ of the appeals were complaints and $27.4 \%$ applications. The applications included the housing problems of the social sphere, social security law, labor law and issues relating to the execution of court decisions and the right to appeal. 53.7\% of the complaints were submitted for consideration, while $64.5 \%$ of them were provided.

Item 1.2 of Report is called protection of economic, social and cultural rights. Current situation of labour law, social provision law, addressed state social aid, the right to health care protecton, education, property, business and human rights and the issues of protection of violated rights in this field, are considered. In 2015, the attorney received 960 appeals on violation of labour rights, 622 addressed social 
aid provision, 445 health care protection, 1225 social provision right violation, 1996 property right. According to appeals, nonpayment of salary, rejection of compensation for production and other damages, non-observation of legislation demands during labour attitudes (travel payments, non-giving the labor book and the order copy upon dismissal and hiring), incorrect calculation of pensions, suggesting family allowance on condition payment of an amount in advance in some cases by some officials of social protection centers established; giving way to bureaucracy; disclose information on issuance of such assistance from the citizens; non- supporting the provision of medicines; lack or shortage of its type or alternates; severe violations admitted in treatment and examination in private medical institutions; very expensive prices; fruitless treatment; the negligence of doctors in public health facilities; unethical behavior of medical staff in respect of patients; lack of sense of responsibility of doctors concerning patients; regardless of medical instruction, the patients' exposure to a variety of laboratory and diagnostic examinations, putting them into a source of profit; lack of medical care quality; improper organization of educational process; the school administration's performing its duties in the manner prescribed; urging citizens to wait for months upon appeal to the Ministry of Education for recognition of diplomas of higher education in foreign countries; delaying the response on the applications regarding housing and individual housing construction by local administration; unreasonable refusal and admittance of bureaucracy; housing queue or restoration of the housing queue; a new apartment instead of building in disrepair; rendering assistance in overcoming the damage caused by natural disaster; providing a plot for the construction of private houses; giving support to repair the house; help to eliminate damage caused to the apartments by neighborhood construction; deceiving and misappropriation of citizens' money by construction companies; selling apartments proposed in new buildings to several people at the same time; doing fraud against them; no result of criminal prosecution against them; not returning misappropriated funds; the demolition of property (house, building) by the local authorities without a court order; redemption failure and non-providing compensation or improper compensation of a privately owned plot for public needs; upon documentation of a citizen's house, apartment and plot giving way to bureaucracy by territorial departments and district (city) departments of State Service of Registration for Real Estate under the State Committee on Property Issues of the Republic of Azerbaijan.

Appeals from different groups of the population including 829 of property, labour, social-provision, health care, education right and other issues by refugees and IDPs, and 550 on children rights. In general, 493, while in 2015, 38 prisoners were pardoned due to the request of the attorney for the term of its activity. 


\section{Conclusion}

Along with those above, taking into account socio-directed activity of the Republic of Azerbaijan, the establishment of "social rights protection" department under this organization should be considered one of the important issues. It is connected with the fact that, statehood experience does not cover far period and legislation basis almost was formed after origination of Constitution, i.e. since 1995 juridical structure is in the stage of improvement. Development directions of legislation in the affairs of coincidence with international standards appears in the period after the 2001 year, i.e. Azerbaijan's becoming member of Council of Europe, that does not cover inefficient terms. Furthermore, the process of legislation improvement creates certain quandaries in the issues of social rights provision (together with modifications): personnel shortage; non-professionality of employees; low level of legal awareness; bureaucratic barriers; procrastination; formal defense, and so on.

So, though various forms of protection of human rights and liberties from illegal actions of Executive Power bodies exist, currently one of the actual problems is an improvement of social laws' protection mechanism upon realization of compulsory administrative events by these bodies. It is true that, despite administrative court serves this purpose directly, strict financial supervision complemented each other, public control and state control must be created from the aspect of productiveness of public law.

\section{References and notes:}

Selivanov A.A, Strizhak A.(2010). The questions of constitutional theory in Ukraine. Topical issues of modern development of constitutional justice - Kiev: Logos.

Rzayev A.N.(2016). Personality, State, Miracle. Baku, "Baku University” Edition.

"Comments on Article 449.2.3 of CPC of Azerbaijan Republic. The decision of Constitutional Court Plenium dated 5 August 29.

Abdullayev. F.S.(2013).A legal stand of Constitutional Court, Baku.

Guliyev.A.(2015).First Generation Azerbaijani immigrants in the United States:Sociocultural characteristics and identity issues.Khazar Journal of

Humanities and Social Sciences.Baku, Azerbaijan,Vol 18,No.2,pp.70-91.

Aghayev.I.B.(2010) The Criminal|Law of Azerbaijan Republic. General and special parts. Textbook. Baku: "Nurlar" Edition.

Smolenskiy M.B.(2004). Advocacy activity of the Russian Federation. Edition 3., Rostovon-Don, Phoenix, 2004.

Aliyev. S.F.(2012). Administrative Law. Textbook. Baku, "Baku University” Edition.

Aliyev.S.I.(2012).Advocacy law. Textbook. Baku. 
Aliyev. S.I.(2015). Theoretical and practical problems of social rights defense in modern international and inter-governmental law. Baku.Report of Human Rights Commissioner (Ombudsman) for 2015.

Shemshuchenko .Y.S., Shcho. E.(2005). Right / Anthology of Ukrainian legal pillows: 10 volumes. 10th volume, $\mathrm{K}$.

Asgarov. Z.A.(2005). Constitutional Law. Textbook.Baku, 2002. Human rights. Associate member of Russia Academy of Sciences, Doctor Of Law, Professor E.A.Lukasheva's edit. Translation Sh.I.Aliyev. Baku.

\title{
Summary
}

\section{National Mechanisms for Ensuring Social Rights}

\author{
Shahriyar Aliyev \\ Baku State University, Azerbaijan
}

The paper highlighted the role of national mechanisms for the protection of social rights. For this purpose its judicial and administrative remedies have been analyzed. The significance of the constitutional protection of the justice system, her legislative experience in the field of social security, legal and regulatory framework, features, procedural and substantive issues considered on the basis of scientific and theoretical considerations. Along with this, the paper considers a system of judicial protection of social rights, it's civil, administrative and judicial properties, and shows the primary form of protection issues.

Through administrative remedies and the Institute of Human Rights Commissioner (Ombudsman), the paper examined the current legal framework for the protection of social rights, and analyzed their activity in this field. As a result, the author has put forward a number of recomendations.

Key words: Social rights, The constitutional review, The Constitutional Court, Supreme Court, Administrative-economic courts, The Criminal Code, Administrative and legal form, The institution of the Ombudsman. 